\title{
THE ALFRED LEEDS FOSSIL VERTEBRATE COLLECTION OF THE NATIONAL MUSEUM OF IRELAND—NATURAL HISTORY
}

\author{
RICARDO ARAÚJO, ADAM S. SMITH ${ }^{1}$ AND JEFF LISTON
}

(Received 05 October 2007. Accepted 14 August 2008.)

\begin{abstract}
Alfred Nicholson Leeds (1847-1917) is famous among vertebrate palaeontologists for amassing an invaluable collection of fossil vertebrates from the Middle Jurassic aged 'Oxford Clay' deposits of the Peterborough district in the UK, throughout the late nineteenth and early twentieth centuries. Part of his collection was acquired by the National Museum of Ireland-Natural History in November 1893 but has not previously been described. This fossil material includes a suite of Jurassic marine reptiles: crocodiles, plesiosaurs and ichthyosaurs. There are no examples, however, of the giant fish Leedsichthys; the remains of which are commonly found among the fauna of the Oxford Clay Formation. Despite representing only a very small fraction of the total Leeds Collection, the specimens in Ireland are significant historically, and have scientific value in their own right. For the first time, in this paper, a historical review of the Dublin Leeds Collection is presented, the fossil specimens described and a long-lost piece of important documentation is presented.
\end{abstract}

\section{Historical review of the Leeds Collection}

Since the nineteenth century the clay pits of the Peterborough district, UK, have yielded a huge number of marine reptile remains. The collection housed in the NMINH (National Museum of Ireland-Natural History), although a very small fraction of the Leeds Collection in total, is valuable because of its historical relevance and the intrinsic scientific value of its fossils. Although primarily known for its Callovian age marine reptile skeletons, the Oxford Clay also yields fish, including the giant suspension-feeder Leedsichthys (Liston and Noè 2004), and dinosaurs (Liston and Noè 2008). Alfred Leeds also included coprolites and invertebrate fossils (e.g. bivalves like Trigonia, belemnites and ammonites) in many of his sales, to provide institutions with a representative faunal suite for the Oxford Clay. General overviews of the Leeds Collection were undertaken by Andrews (1910) and Leeds (1956).

The collection was amassed by Alfred Leeds between c. 1867 and 1917 (Leeds 1956) when he assumed the management of his family's farm in the Peterborough district, Cambridgeshire. Charles Leeds, his elder brother, occupied a minor role in the collection of specimens before he emigrated to New Zealand in 1887. Charles was originally encouraged by Professor John Phillips, Lecturer in Geology at Oxford University, to preserve and continue collecting fossils from the Peterborough brick pits (Woodward 1917) and Phillips was the first palaeontologist to publish a paper on specimens in the collection

\footnotetext{
${ }^{1}$ Research related to this paper was carried out while the author was affiliated to the School of Biology and Environmental Science, University College Dublin.
} 
(Phillips 1871), describing plesiosaur and pliosaur remains. Another isolated encounter between the collection and professional palaeontologists came in 1874, when the well-known fossil reptile specialist Harold (Harry) Govier Seeley came to Eyebury - the Leeds' residence and fossil store (Leeds 1956) - and subsequently published two papers (Seeley 1874a, $1874 \mathrm{~b}$ ) on partial skeletons of new genera in the collection. But it was not until almost twenty years after the inauguration of the Leeds Fossil Collection that it came to the attention of the general scientific community, when in 1885 Alfred Leeds first contacted Henry Woodward, Keeper of Geology in the British Museum (Natural History),- BMNH. The surprising lack of further visits during this early period has been commented on at length by Leeds' son Edward Thurlow Leeds in his history of the collection (Leeds 1956) - it was clear that this was a new and significant resource, yet no one appears to have responded to the publications by Phillips and Seeley by seeking out this collection for themselves. As E.T. Leeds comments, it may be down to the lack of inclination of the Leeds brothers to approach anyone, perhaps because in the early days of the collection they could obtain the information that they needed from publicly available books. Following Alfred Leeds' contact, Henry Woodward visited the collection at Eyebury, an event that was to prove noteworthy for two reasons: (1) his visit spurred other palaeontologists to follow (R. Lydekker, J. W. Hulke and even O. C. Marsh); and (2) the friendly relationship which developed between $\mathrm{H}$. Woodward and A. Leeds became fruitful for the $\mathrm{BMNH}$, the institution now boasting the choicest parts of the collection (Woodward 1917). Woodward became interested in acquiring this collection (cited in Leeds 1956) and by 1890, five years after his initial visit, the BMNH agreed to purchase the items (about $5,000 \mathrm{~kg}$ of bones). The Leeds Collection is nowadays dispersed throughout Britain (e.g. the Hunterian Museum, University of Glasgow, houses the bulk of the collection, over 600 specimens purchased from Leeds' son, Edward Thurlow, and the Royal Scottish Museum in Edinburgh has some material obtained via Stürtz (see below)); Germany (e.g. Tübingen and the Goldfuss Museum of Bonn); Austria; France; Sweden (Uppsala); the USA (Peabody Museum, Yale University) and Ireland (Woodward 1917; Neaverson 1935; Liston and Noè 2008; this paper). The purpose here is to outline the history of the Dublin Leeds Collection, and provide a catalogue of the specimens together with additional anatomical information and illustrations where appropriate.

\section{The Dublin Leeds Collection}

The correspondence files of the NMINH show how the relationship between Alfred Leeds and the Dublin Science and Art Museum (as the NMINH was then known) developed. As recorded by Alfred Leeds, he first made an approach to the institution in October 1892, asking if it would like to 'purchase some fossil bones' (Alfred Leeds to Robert Scharff, 3 August 1893-NMINH SA Letter File, 1893, Vol.3; note that all references in this section to Leeds correspondence refer to A.N. Leeds, unless otherwise stated. All correspondence referenced in this article is summarised in Table 1). At the time, the Science and Art Museum informed him that their annual purchase grant had

Table 1-List of correspondence referenced within this paper, ordered by appearance.

\begin{tabular}{lll}
\hline Archival reference & Details & Date \\
\hline NMINH SA Letter File, 1893, Vol. 3 & Alfred Leeds to Valentine Ball & 22 October 1893 \\
NMINH SA Letter File, 1893, Vol. 3, & & 1893 \\
No. 508 & & \\
NMINH SA Letter File, 1893, Vol. 3 & Alfred Leeds to Valentine Ball & 12 October 1893 \\
NMINH Letter File, 1893, Vol. 3 & Valentine Ball to Alfred Leeds & 21 October 1893 \\
NMINH & $\begin{array}{l}\text { Minute Paper by Robert Francis Scharff, } \\
\text { Keeper of Natural History at NMINH }\end{array}$ & 9 November 1893 \\
NMINH 1896.L & Correspondence Files & 1896 \\
NMINH SA Letter File, 1893, Vol. 3 & Alfred Leeds to Robert Sharff & 3 August 1893 \\
NMINH SA Letter File, 1893, Vol. 3 & Alfred Leeds (informal list of the specimens) & 1893 \\
\hline
\end{tabular}


been spent, but that he should renew his offer in the future. Alfred Leeds repeated his offer in August 1893, inviting museum representatives to visit his collection to view what he was offering, and he pointed out how conveniently located he was with respect to journeys from either London which was one and a half hours away or Nottingham, which took one-quarter of an hour less (Alfred Leeds to Robert Scharff, 3 August 1893NMINH SA Letter File, 1893, Vol.3).

Within two days, a discussion ensued between Dr Robert Francis Scharff, Keeper of Natural History, and Dr Valentine Ball, Director of the then Dublin Science and Art Museum (now NMINH), both enthusiastic to procure items, and in agreement that Ball should visit Eyebury from Nottingham (Minute Paper between Valentine Ball and Robert Scharff, 5-7 November 1893). Implicit within this dialogue is that Ball had already arranged to attend a meeting in Nottingham prior to Alfred Leeds' letter, and although it is very likely that it was the Sixty-Third Meeting of the British Association for the Advancement of Science, held at Nottingham in September 1893 (British Association for the Advancement of Science 1894), no information is given to corroborate this. A telegram was sent by Ball to Scharff from the Conference Hall in Nottingham, arriving in Dublin on the 21 September 1893, announcing that he was 'going to see the bones' and asking if it might be possible to spend up to $£ 50$ if it was 'desirable' to do so-presumably this was dependent on his imminent assessment of the material at Eyebury (NMINH SA Letter File, 1893, Vol. 3). Ball's visit must indeed have been brief, as he does not sign the Eyebury Visitors' Book for the end of September (when Henry Woodward, Keeper of Geology in the BMNH and his wife were visiting); but the material must indeed have been 'desirable', as a request for funding from Ball reached the Lords of the Committee of Council on Education at the Department of Science and Art in London the next day, and by the 26 September they had given their sanction to spending $£ 70$ on 'Bones of saurians \&c.' for the Dublin Museum of Science and Art (26 September 1893, NMINH SA Letter File, 1893, Vol. 3, No. 508).

As in the previous year, however, budgetary constraints intervened, and by the 5 October 1893 Ball informed Alfred Leeds that $£ 35$ could be paid, with the balance forthcoming after 1 April, presumably reflecting the commencement of the institution's next financial year. Alfred Leeds appeared undeterred by this payment in instalments, and by 22 October dispatched a 'holding' letter to Ball, informing him that Leeds had been away from home and thus was delayed in completing the packing of the material (Alfred Leeds to Valentine Ball,
12 October 1893-NMINH SA Letter File, 1893, Vol. 3). On the 2 November Leeds sent Ball a further letter to confirm that all the specimens were packed with details of how to extricate a mounted ichthyosaur paddle that he had secured within one crate, and expressing the hope that everything would 'travel safely' (Alfred Leeds to Valentine Ball, 2 November 1893-NMINH SA Letter File, 1893, Vol. 3). He also indicated that he had forgotten to include belemnites, but would send them as soon as he could. The material was entered in the accession register by Scharff on 9 November 1893 (NMINH 1893.156-74), and he certified the accounts the same day as, although an Asteracanthus dorsal spine had not been sent, it had been intended as a gift rather than a purchased item (Minute Paper by Robert Francis Scharff to Valentine Ball, 9/11/1893). Alfred Leeds wrote again to Ball to express his relief at the safe arrival of the consignment, as he,

was very much afraid that the heads might come to grief on the journey-I think that I could not have put the spine of Asteracanthus in the box. I know I picked one out to send-but certainly did not put it in the little box-so one shall be looked out and sent you by post. I sent some belemnites by post last week \& hope you have received them.

(Alfred Leeds to Valentine Ball, 12 November 1893-NMINH SA Letter File, 1893, Vol. 3)

Although in his letter of 2 November 1893 Alfred Leeds indicated that if his list of specimens did "not tell you all you want to know about the specimens-I shall be glad to answer any questions I can-I think I have put in all the bones agreed upon by us - if not please let me know' (Alfred Leeds to Valentine Ball, 2 November 1893-NMINH SA Letter File, 1893, Vol. 3), it seems that the staff at Dublin were slow to take him up on his offer. This may have been because a recent policy of employing external curators to catalogue the fossil collections had lapsed, and there was simply not the staff to keep on top of new material as it came in. Whatever the reason, it was three years before an enquiry arrived asking for more information, including whether or not the specimens had been described, and Alfred Leeds replied (Letter from Alfred Leeds, 28 October 1896NMINH, October 1896 Correspondence File) indicating that he could not remember what he had sent, and had kept no record. He offered some crocodile remains for sale ('I believe I get nine or ten distinct species') but no further purchases appear to have been made by the Dublin Museum of Science and Art (Letter from Alfred Leeds, 28th October 1896-NMINH, October 1896 Correspondence File). 
The Dublin Leeds Collection is noteworthy because it was the first suite of material sold by Alfred Leeds to an institution other than the BMNH, prior to Leeds establishing a relationship with the Bonn dealer Bernhard Stürtz in 1897. One clear drawback of this collection, however, is that no precise information about the geological horizon was provided for any of the Dublin Leeds specimens. Andrews (1910) states that 'the horizon at which [Oxford Clay] reptilian bones occur is that characterised by the presence of the "Ornatus" group of Ammonites' (p. vi), particularly Cosmoceras gulielmii. Arkell (1933 in Duff 1975) further specified the zone in which reptile remains are found, to Kosmoceras jason (Middle Callovian). The Dublin Leeds Collection therefore probably originated from this zone of the 'Lower Oxford Clay'. Although precise stratigraphic positions can retrospectively be determined for some of Alfred Leeds' specimens from his excavation records in the 'Eyebury Register', the only notes relating to the Dublin specimens do not contain salient information.
Systematic palaeontology

Crocodylomorpha Hay, 1930 (sensu Walker, 1970)

Crocodyliformes Hay, 1930 (sensu Benton and Clark, 1988)

Thalattosuchia Fraas, 1901

Metriorhynchidae Fitzinger, 1843

Metriorhynchus Meyer, 1830

Metriorhynchus superciliosus (de Blainville, 1853) Eudes-Deslongchamps, 1867-9

\section{Material}

Specimen NMING F16892 (Fig. 1A) comprises a skull (almost complete) and lower jaw, associated with 16 vertebrae. Specimen NMING F21731 (Fig. 1B) consists of the skull (almost complete) and the lower jaw, 28 vertebrae and both ilia. The skull has been slightly dorso-ventrally compressed. The dorsal skull bones bear smooth ornamentation and dorsal crests occur on the parietal and squamosal. NMING F21760 is an isolated left femur.

The skulls of the NMING F16892 and NMING F21731 measure $600 \mathrm{~mm}$ and $670 \mathrm{~mm}$ respectively, according to Vignaud's (1995) standardised measurements

\section{A}

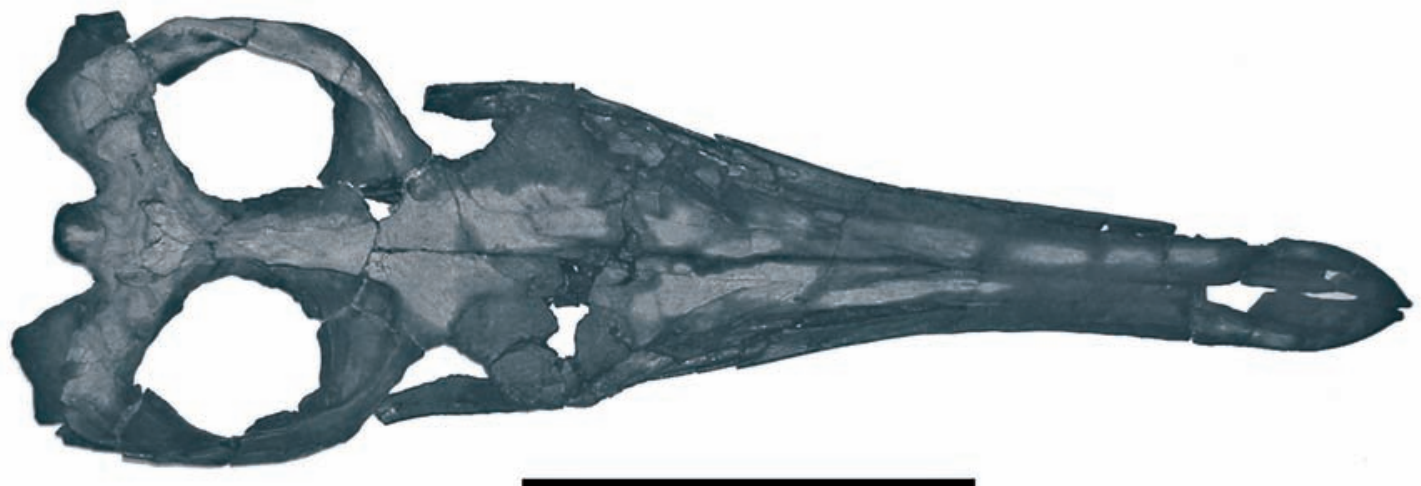

B

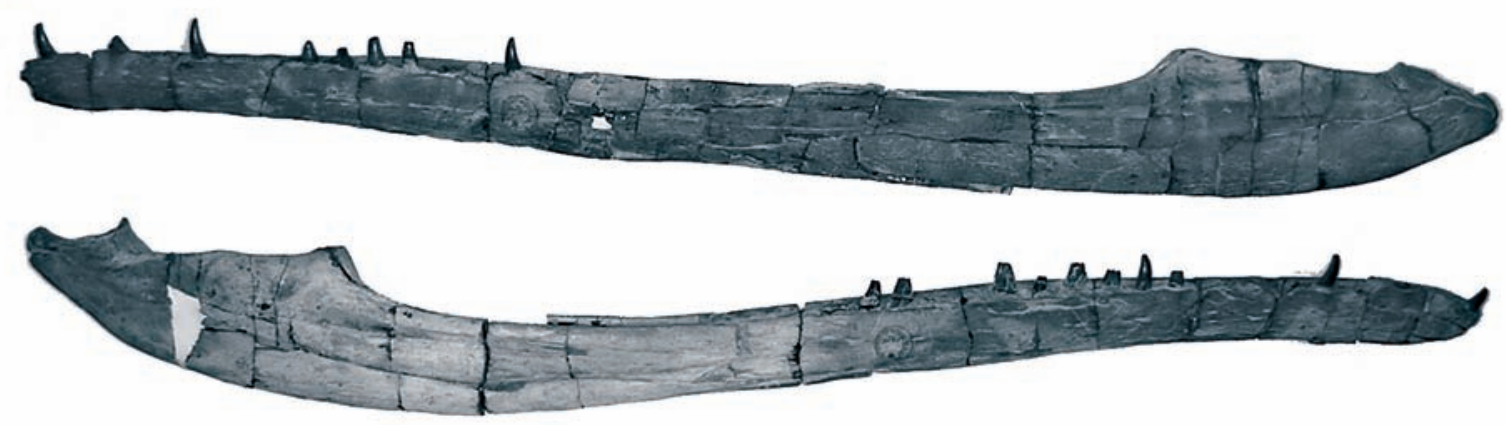

Fig. 1-Skull of Metriorhynchus (in dorsal view) and both lower jaw rami (in lateral view). A. Specimen NMING F16892; B. Specimen NMING F21731. Scale-bar equals $30 \mathrm{~cm}$. 
and the nasal bones are 230mm (NMING F16892) and 255mm (NMING F21731) long. The supratemporal fossa is $115 \mathrm{~mm}$ (NMING F16892) and 140mm (NMING F21731) long, $60 \mathrm{~mm}$ and $90 \mathrm{~mm}$ wide respectively. The lower jaw of the NMING F21731 measures 715mm in length, the mandibular symphysis is $400 \mathrm{~mm}$ long and the mandibular tooth row spans $335 \mathrm{~mm}$.

\section{Discussion}

Both the Metriorhynchus skulls were prepared in 2004 at University College Dublin; F16892 was originally embedded in paraffin wax and only the dorsal surface of the skull was exposed (Gandola et al. 2006). The associated postcranial material is generally wellpreserved despite some vertebrae lacking neural arches. The skull of NMING F21731 is broken into five pieces, since it was originally repaired with natural animal glue. The specimen exhibits dorso-ventral flattening post mortem deformation. Specimen NMING F21731 has dorsal crests on the parietal and squamosal, and pitted ornamentation on the frontal and prefrontals. These characters combined with the skull proportions are diagnostic for M. superciliosus (Vignaud 1995; Adams-Tresman 1987a). The postcranial material-28 vertebrae-are broken into pieces. The taphonomy of this specimen is interesting since anterior and posterior remains of the specimen are found together. An interesting anatomical feature in Metriorhynchus, salt glands in the antorbital cavity, was first detected in these specimens (Gandola et al. 2006).

The isolated left femur NMING F21760 was initially suggested by A. Leeds as also belonging to Metriorhynchus (informal list of the specimens by Alfred Leeds-NMINH SA Letter File, 1893, Vol. 3). This femur is similar to Steneosaurus, but one autapomorphic character, an extended ventrally roughened trochanter, is absent in Steneosaurus.

Teleosauridae Geoffroy, 1831

Steneosaurus Geoffroy, 1825

Steneosaurus edwardsi (Eudes-Deslongschamps, 1868) Eudes-Deslongchamps, 1867-9 sensu Vignaud, 1995

\section{Material}

Specimen NMING F21732 (Fig. 2A) comprises the anterior part of the skull (Fig. 3A) and mandible ( $60 \%$ of total), two isolated teeth, tarsal bones (a right calcaneum and a right fifth metatarsal), 16 vertebrae including the atlas-axis (Fig. 3B) and rib fragments. Specimens NMING F21762, NMING F21763 are deduced to be additional teeth from two different individuals, due to the different preservation.
The measurements are standardised from Vignaud (1995). The total length of the skull is estimated as $900 \mathrm{~mm}$, with $270 \mathrm{~mm}$ between the premaxillary bone and the anterior end of the nasal. The maximum length of the orbit is $60 \mathrm{~mm}$ and its perpendicular length is $45 \mathrm{~mm}$. The width of the skull measured on the anterior edge of the orbits is estimated as $150 \mathrm{~mm}$, while the atlas-axis complex (including the atlantal ring) measures $73 \mathrm{~mm}$ in length, $40 \mathrm{~mm}$ in width and $9 \mathrm{~mm}$ in height (estimated). The preserved cervical vertebrae range in central length from $46 \mathrm{~mm}$ to $49 \mathrm{~mm}$ and in width from $36 \mathrm{~mm}$ to $47 \mathrm{~mm}$. The dorsal centra range from $50 \mathrm{~mm}$ to $56 \mathrm{~mm}$ in length, $44 \mathrm{~mm}$ to $48 \mathrm{~mm}$ in width, and including the neural arch (from the vertebrae where preserved) are $95 \mathrm{~mm}$ to $103 \mathrm{~mm}$ in height.

\section{Discussion}

The most striking feature of NMING F21732 is its long narrow snout (Fig. 3A). In addition, the square-like supratemporal fenestrae, the large forward pointing external nares, the long mandibular symphysis and the latero-dorsally orientated subcircular orbits are important autapomorphies of the genus Steneosaurus (Adams-Tresman 1987b; Vignaud 1995). We have attempted to assign NMING F21732 on the basis of our anatomical observations. Some species can be readily excluded-S. bollensis, S. leedsi and S. megarhinus-because they share the longirostrine condition and have finely built skulls (Andrews 1913). Among the most well-preserved brevirostrine taxa, S. obtusidens, S. edwardsi and $S$. bouchardi are the best candidates for this assignment. S. obtusidens, however, possesses a different dental formula-although this is a very weak character since it can vary intraspecificially-in the lower jaw and the characteristic pointed and curved shape of the teeth of S. obtusidens is not detected in NMING F21732. Steneosaurus bouchardi has never been reported from the Jurassic of the UK, and, unlike NMING F21732 belongs to the Upper Kimmeridgian. This crocodile also has a heavily built skull; its supratemporal fossae are rectangular and it has a marked antorbital foramen (Vignaud 1995). On the basis of these arguments, $S$. edwardsi seems to be the most plausible species for referral of NMING F21732; not only are the proportions of the skull similar, but also the dental formula, the absence of the antorbital foramen and the circular shape of the orbits are characteristics shared by NMING F21732. The $S$. edwardsi specimen BMNH R2075-collected from the same general locality-stored in the Natural History Museum (London) also exhibits a very similar preservation to NMING F21732. 

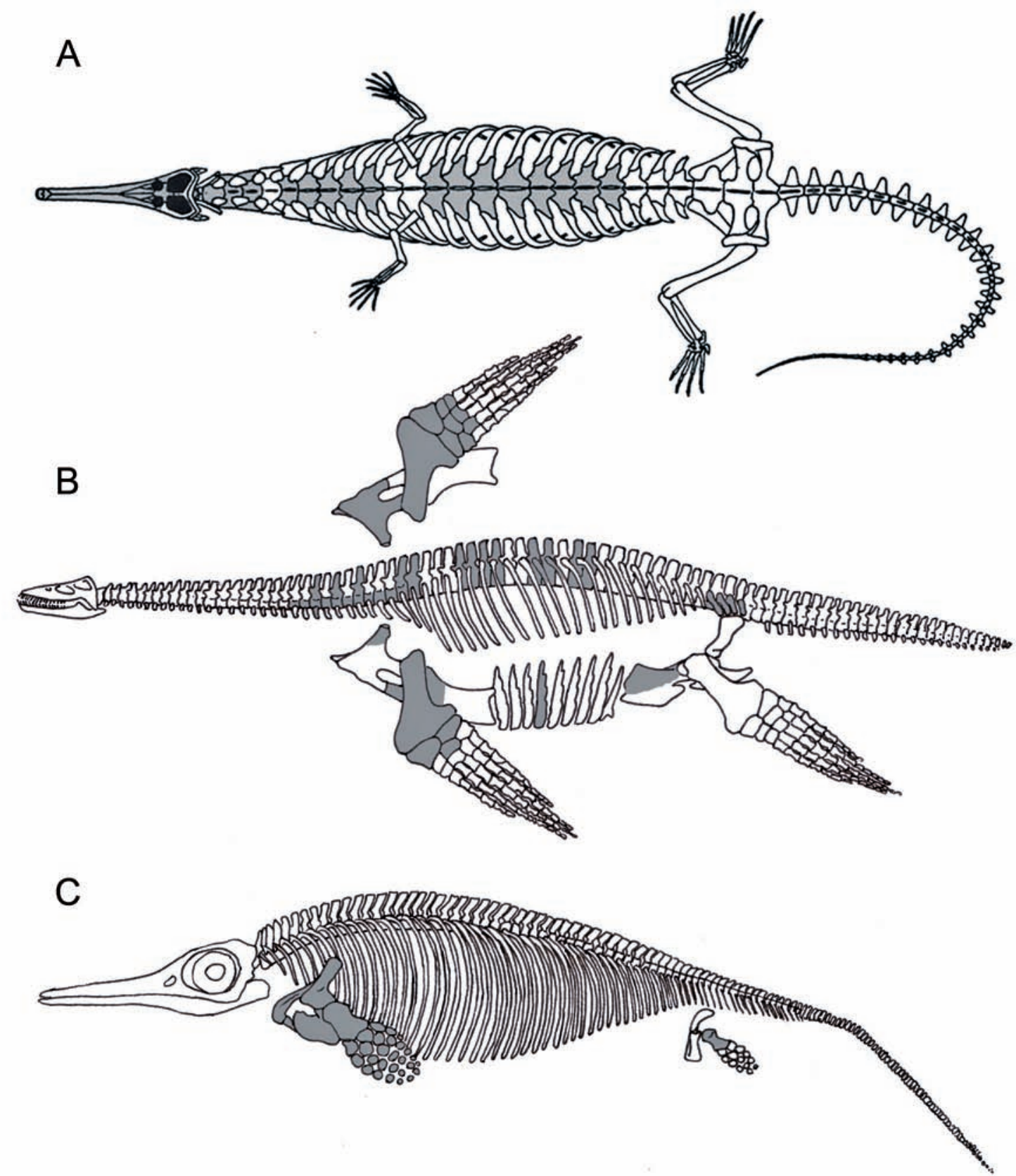

Fig. 2-Outline of three marine reptiles' skeletons, showing the elements preserved in the most complete specimens (shaded grey) within the Dublin Leeds Collection. A. Steneosaurus edwardsi, in dorsal view (NMING F21732); B. Cryptoclidus eurymerus, in lateral view (NMING F21786); C. Ophthalmosaurus icenicus, in lateral view (NMING F21787). A is based on a Teleosaurus from Steel (1973). B and C are based on Andrews (1910). Not to scale. 


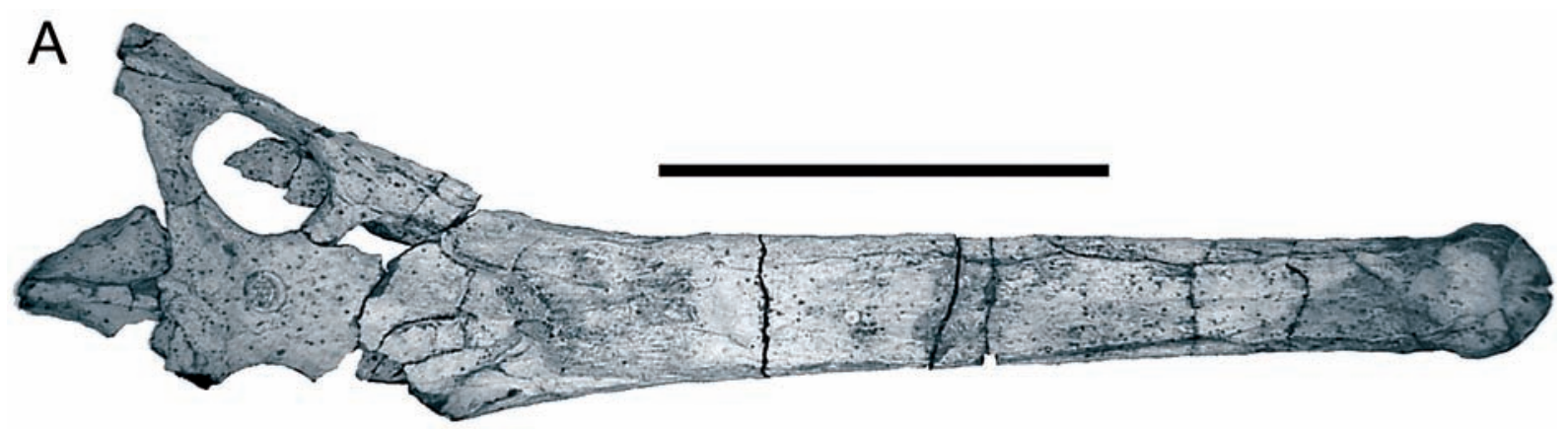

B

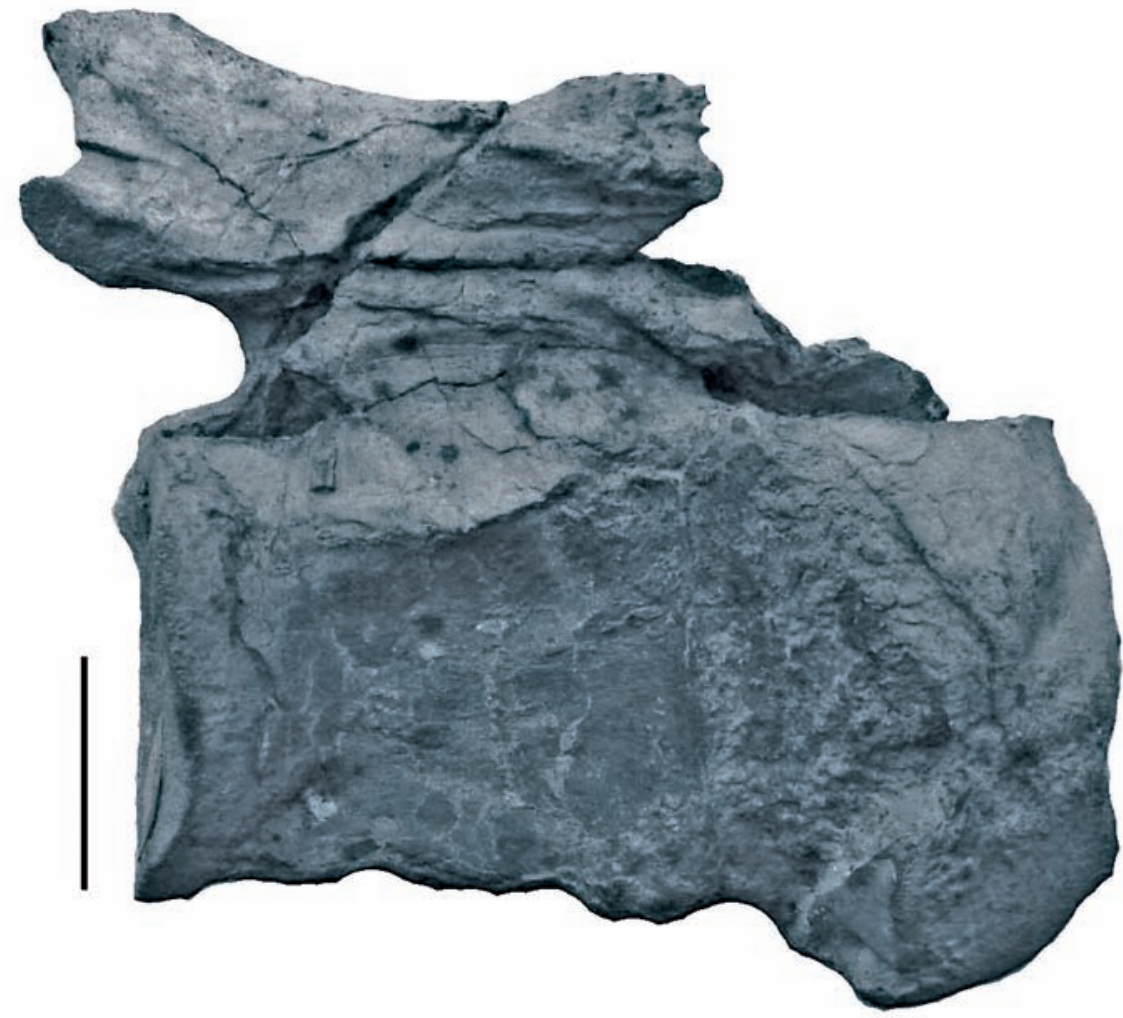

Fig. 3-Specimen NMING F21732 ascribed here to Steneosaurus edwardsi, some bones preserving important diagnostic features. A. Skull in dorsal view; B. Atlas-axis complex in lateral view. Scale-bar in A equals $20 \mathrm{~cm}$ and in B equals $1 \mathrm{~cm}$. 
The vertebrae of NMING F21732 are all slightly distorted, so that in six of them the anterior articular facet is sheared to the left, relative to the posterior articular facet, and in seven the anterior facet is displaced to the right. This indicates that the neural spine was not in close articulation in situ, and may also explain why so much of the rest of the skeleton is missing (i.e. due to dispersal on the seabed prior to burial). The element identified as a fifth metatarsal is uncertain due to the poor preservation of the bone.

Plesiosauria de Blainville, 1835

Plesiosauroidea Gray, 1825

Cryptoclididae Williston, 1925

Cryptoclidus Seeley, 1892

Cryptoclidus eurymerus (Phillips 1871) Seeley, 1892

\section{Material}

The remains of four specimens of Cryptoclidus are included in the Dublin Leeds Collection. The most complete individual is NMING F21786 (Fig. 2B) which comprises a large proportion of the vertebral column with neural arches, both humeri (each $260 \mathrm{~mm}$ long, with a distal width of $155 \mathrm{~mm})$, radii $(85 \mathrm{~mm}$ long), ulnae (70mm long), a number of carpals and metacarpals, a complete right scapula (190mm long) and the dorsal process of the left scapula, the anterior part of the left coracoid (preserved part $175 \mathrm{~mm}$ long), a partial clavicle (not figured), a partial pubis $(205 \mathrm{~mm}$ long) and associated rib fragments (Fig. 4).

Specimen NMING F21785 belongs to a larger individual and comprises the distal part of a humerus (305mm wide distally), a radius, two ulnae and a partial ischium (maximum width $230 \mathrm{~mm}$ ), two phalanges,

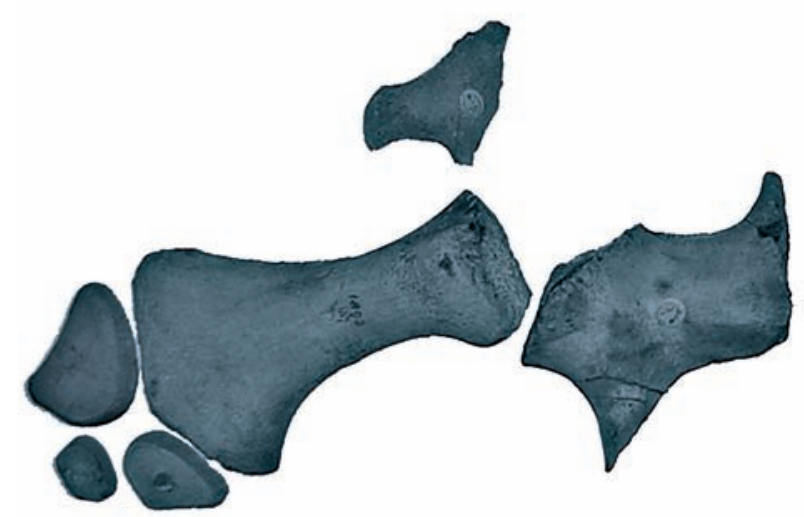

eleven vertebrae, and associated rib fragments. The preservation of this specimen contrasts sharply with most of the other material in the Dublin Leeds Collection; it is likely that this specimen originates from a distinct locality and/or horizon.

Specimen NMING F21782 is an isolated right humerus, partly restored in plaster and almost identical in size and form to the right humerus of NMING F21786.

Specimen NMING F21781 is the poorly developed humerus of a juvenile plesiosaur, probably also referable to Cryptoclidus due to its general morphology.

\section{Discussion}

Cryptoclidus is widely considered to be the most abundant plesiosaur in the Oxford Clay Formation (Martill 1991) and this is certainly the case within the small Dublin collection. The Cryptoclidus material in the Dublin Leeds Collection ranges from juvenile to old adult individual (sensu Brown 1981).

Specimen NMING F21785 is a large specimen of Cryptoclidus in which the preserved parts of the forelimb (humerus, radius, ulna) are diagnostic (Brown 1981) - the radius and ulna have a distinctive shape and there is a clear 'elbow' formed by the angle between the anterior border of the humerus and radius. A small bone fused to the postaxial margin of the ulna is of particular interest (this bone is separate in the second limb but the tight suture shows that it has been broken off post-fossilisation); although labelled as an ulnare, its position is inconsistent with this diagnosis and following Caldwell (1997) should rather be regarded as the pisiform. Fusion of the pisiform occurs late in the ontogeny of this genus and is a character seen in

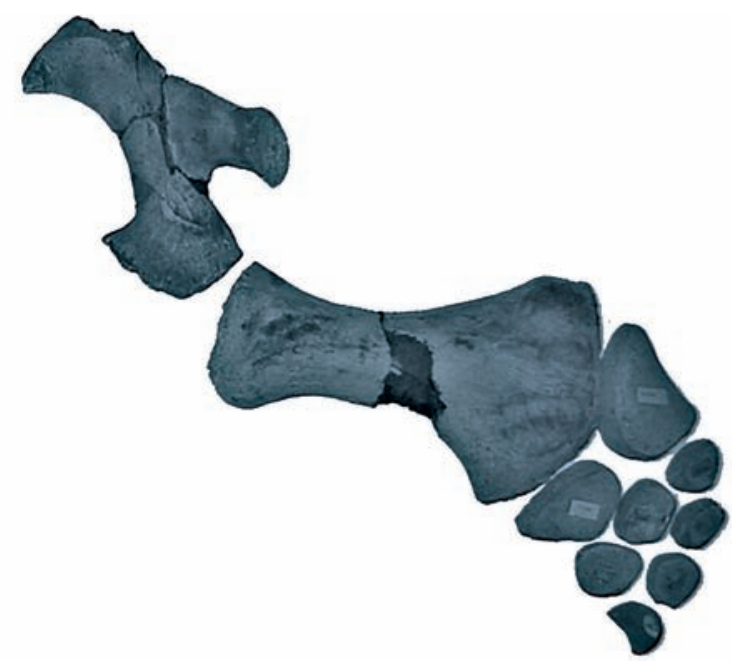

Fig. 4-The partial pectoral girdle and forelimbs of Cryptoclidus eurymerus (NMING F21786) in dorsal view. The full width of the girdle has been reconstructed based on the complete left coracoid. The organisation of the bones in the limbs was based on Caldwell (1997). Scale-bar equals $30 \mathrm{~cm}$. 


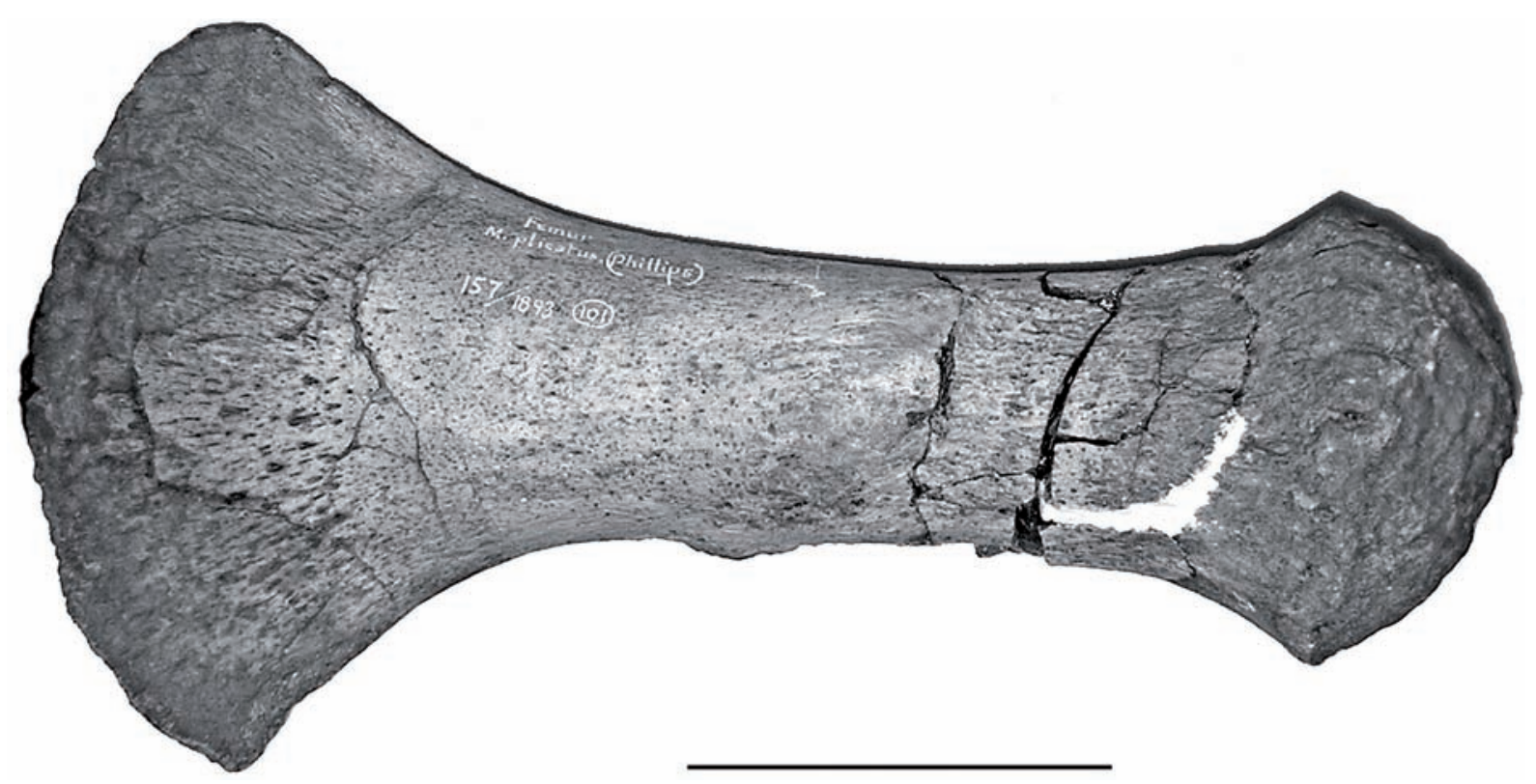

Fig. 5-Right femur of Muraenosaurus beloclis (NMING F21779). Scale-bar equals $10 \mathrm{~cm}$.

'Apractocleidus' (Smellie 1916), a genus regarded by Brown (1981) as an 'old adult' Cryptoclidus. The fused pisiform, fused neural arches and general large size corroborate the status of NMING F21785 as an old individual.

On the other hand, specimen NMING F21786 shows many juvenile characters (Andrews 1895) - a poorly developed pectoral girdle (the anterior process of the scapula does not contact the midline), poorly ossified limbs, and neural arches which are not ossified to the centrum (Fig. 4). The radius of Cryptoclidus, however, is diagnostic even in juveniles, 'being greatly expanded proximally and anteriorly' (Brown 1981, 276).

Muraenosaurus Seeley, 1874a

\section{Muraenosaurus sp.}

\section{Material}

Specimen NMING F21778 is an incomplete right scapula, $250 \mathrm{~mm}$ long. The dorsal process is $140 \mathrm{~mm}$ long on the lateral surface and the ventral process is $150 \mathrm{~mm}$ wide.

\section{Discussion}

The ventral ramus of this incomplete right scapula (NMING F21778) is very broad and well-developed, as in old-adult cryptoclidids, and appears to have met on the midline posteriorly. Anteriorly, the ramus is excavated and separated from its counterpart on the midline, a characteristic of Muraenosaurus (Brown 1981). Apart from size, however, species of Muraenosaurus cannot be differentiated based on scapular morphology alone (Brown 1981).
Muraenosaurus leedsii Seeley, 1874a

Material

Specimen NMING F21779 is a single right femur (Fig. 5), $335 \mathrm{~mm}$ long and $175 \mathrm{~mm}$ wide distally.

\section{Discussion}

There are two valid species of Muraenosaurus described from the UK-M. leedsii and M. beloclis (Brown 1981). Specimen NMING F21779 is labelled as 'M. plicatus', a species now considered synonymous with M. leedsii. Indeed, specimen NMING F21779 most closely approximates $M$. leedsii in the elongate and light construction of the femur (Andrews 1910).

Pliosauroidea Seeley, $1874 \mathrm{c}$

Pliosauridae Seeley, 1874c

Peloneustes Lydekker, 1889

Peloneustes philarchus (Seeley, 1869) Lydekker, 1889

\section{Material}

Two isolated propodial bones, NMING F21783 (Fig. 6A) and NMING F21784 (Fig. 6B) and a tooth (NMING F21761) belong to the pliosaur Peloneustes philarchus.

\section{Discussion}

According to Tarlo (1960) the pliosaur Peloneustes is monospecific. Its propodials are quite distinct from other plesiosaur species in their bi-symmetrical tear-drop shaped outline (see Fig. 6). The humerus of Peloneustes is much broader than the femur (Andrews 1913) and on 


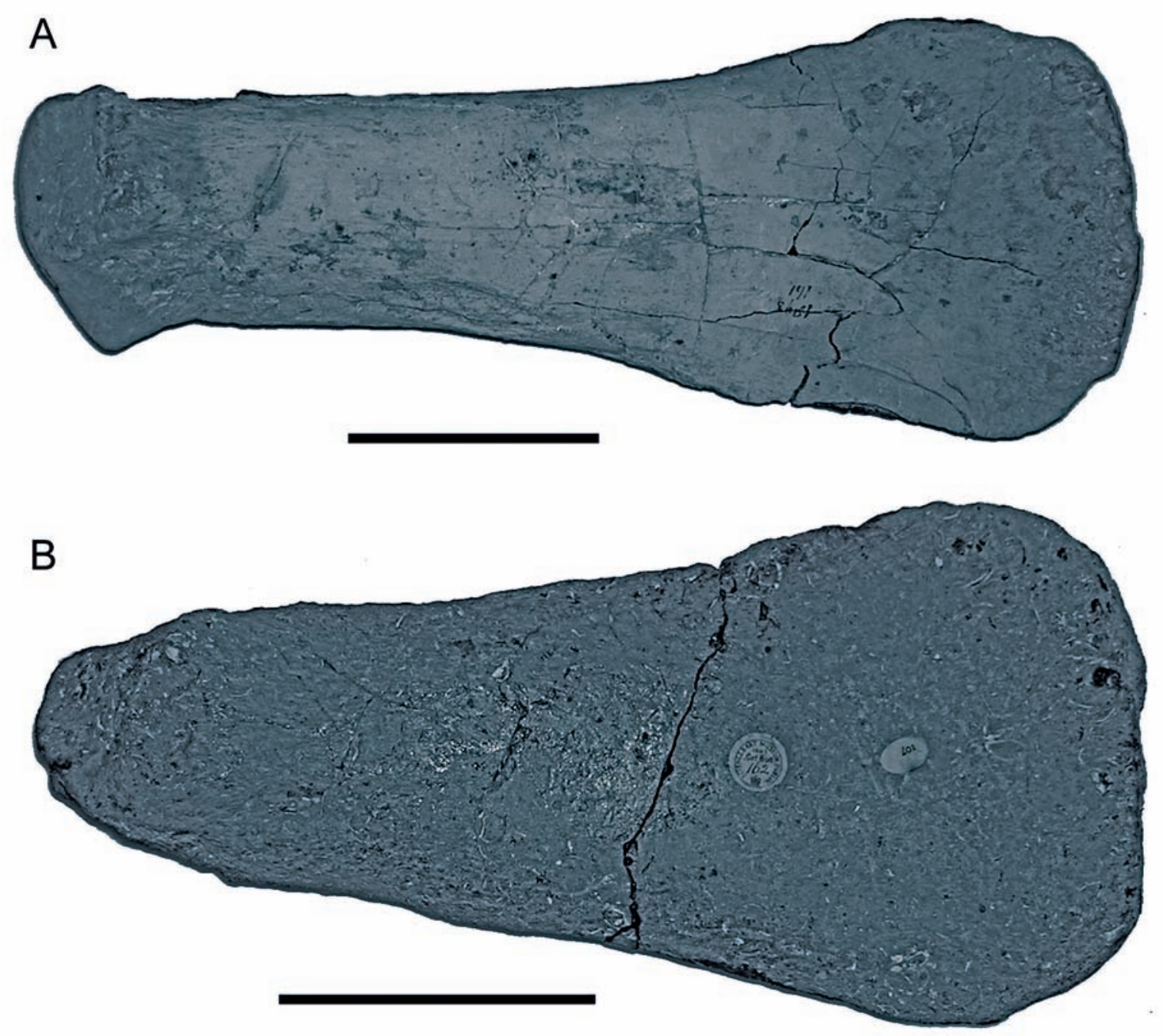

Fig. 6-Pelonestes philarchus. A. Femur (NMING F21783); B. Humerus (NMING F21784). Scale-bars equal 10cm.

this basis specimen NMING F21784 may be a humerus, and NMING F21783 a femur. The tuberosity of NMING F21784 is small, however, and contradicts the usually strongly developed condition seen in Peloneustes (Andrews 1913), perhaps indicating the immaturity of the individual. The pattern of ornamentation on the isolated tooth (NMING F21761) is diagnostic (Martill 1991), therefore we assign this specimen to Peloneustes.

Plesiosauria indet.

\section{Material}

Specimen NMING F21780 is a single complete ilium, $205 \mathrm{~mm}$ long.

\section{Discussion}

The most notable feature of this isolated ilium is a sharp kink in its shaft, which differs from the lightly curved ilia seen in all other Oxford Clay Formation plesiosaurs (see figures in Andrews 1910). Thus, this bone is temporarily regarded as Plesiosauria indet. despite its apparently distinctive morphology.

Ichthyopterygia Owen, 1840

Ichthyosauria de Blainville, 1835

Ophthalmosauridae Baur, 1887

Ophthalmosaurus Seeley, 1874b

Ophthalmosaurus icenicus Seeley, 1874b

\section{Material}

This specimen (NMING F21787) consists of an almost complete pectoral girdle (Fig. 7), both humeri, 80 paddle bones including one complete paddle (Fig. 8A), two cervical ribs, and a femur (Fig. 2C). The scapulae are $220 \mathrm{~mm}$ long and $125 \mathrm{~mm}$ wide; the minimum distance between the scapulae as articulated is $280 \mathrm{~mm}$. Each humerus is $155 \mathrm{~mm}$ long, and $140 \mathrm{~mm}$ wide distally. 


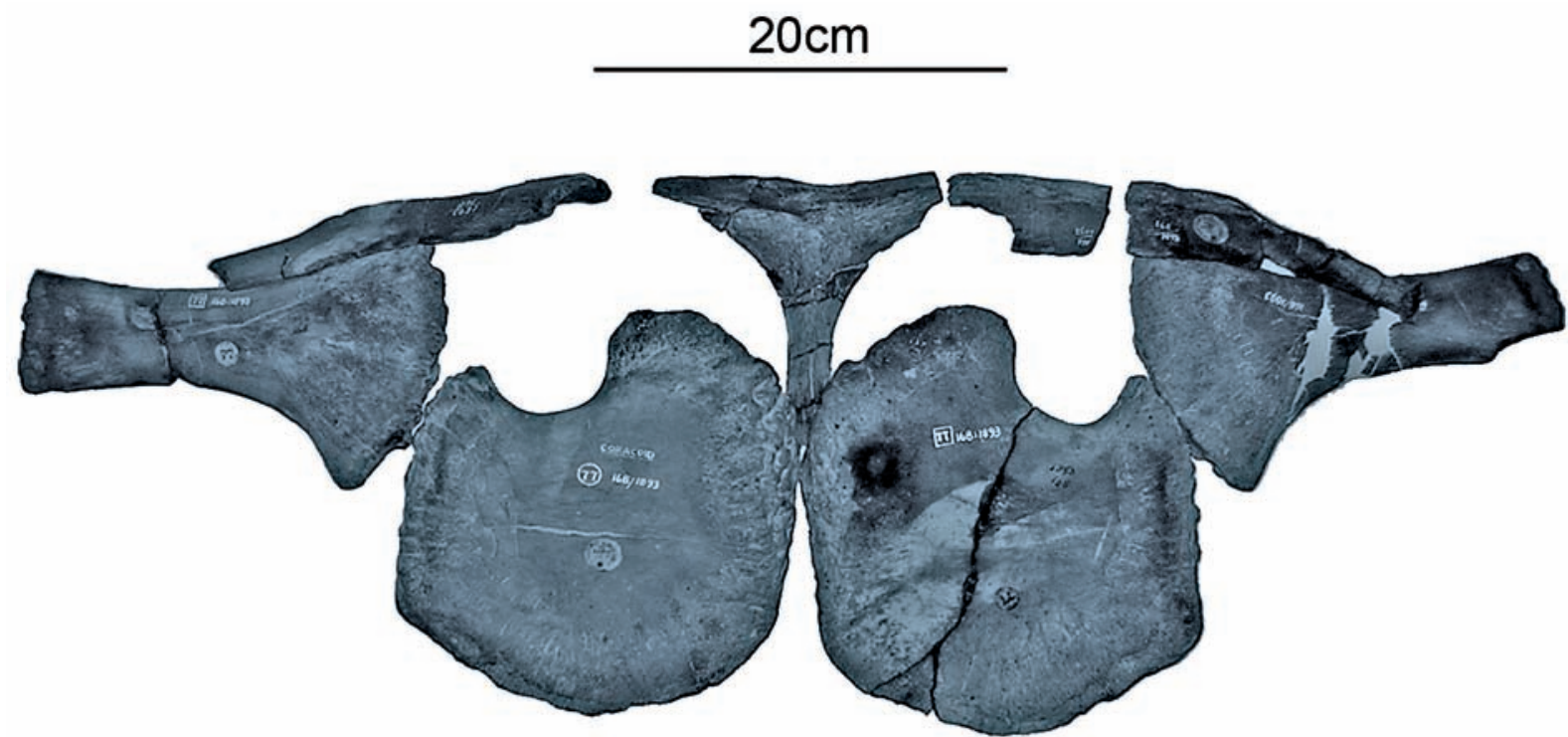

Fig. 7-Reconstructed pectoral girdle of Ophthalmosaurus icenicus (NMING F21787) in dorsal view. Scale-bar equals $20 \mathrm{~cm}$.
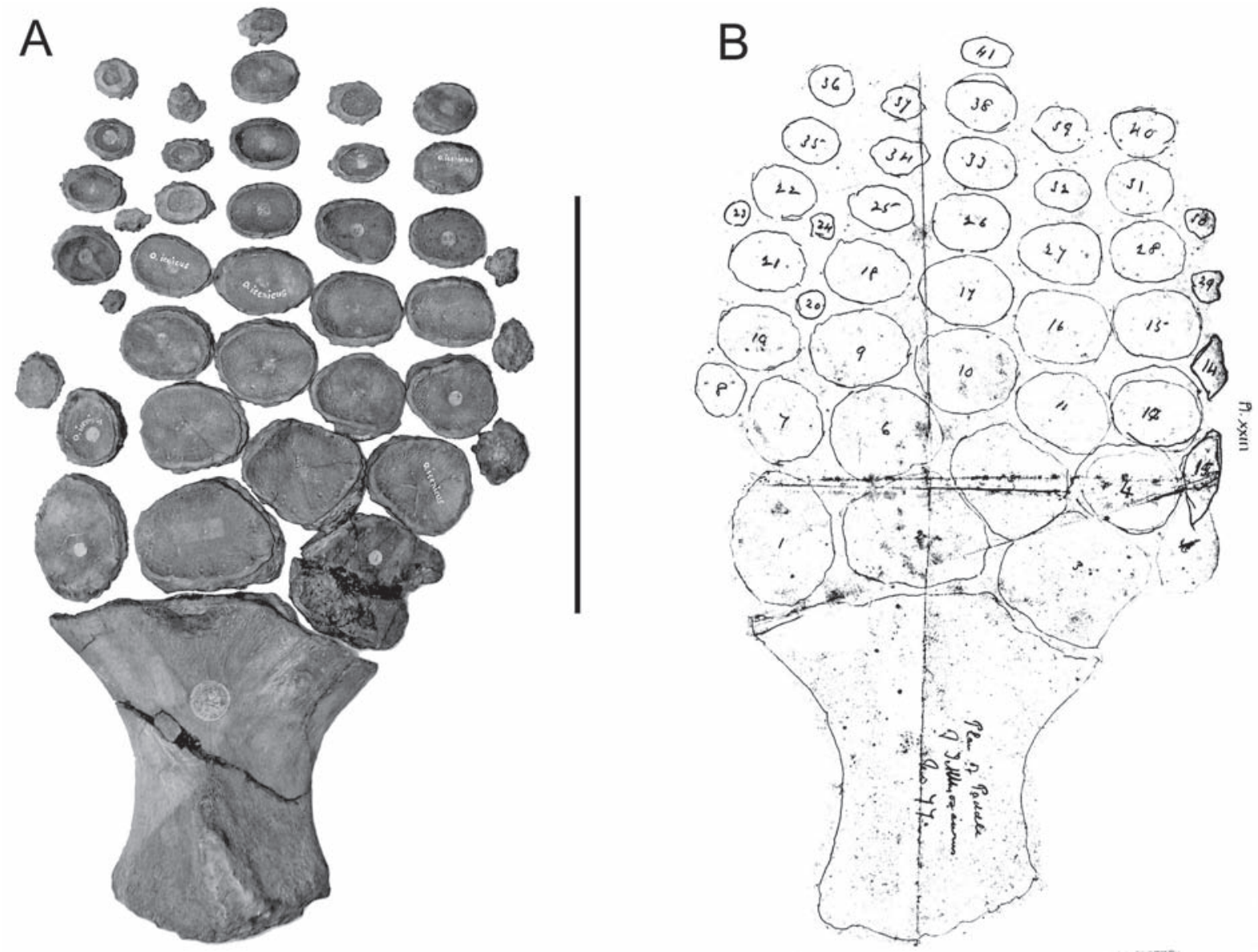

Fig. 8-Left paddle of Ophthalmosaurus icenicus (NMING F21787) in dorsal view. A. Reconstruction of the limb; B. Original in situ illustration by Alfred Leeds. Scale-bar equals $20 \mathrm{~cm}$. 


\section{Discussion}

The genus Ophthalmosaurus is characterised by a flared proximal end of its scapula (Maisch and Matzke 2000) and in the morphology of the humerus and phalanges, (McGowan and Motani 2003; Sander 2000), all of which are preserved in NMING F21787. According to correspondence from A. Leeds (Letter from Alfred Leeds, 28 October 1896, Correspondence File 28/2/1896), the complete Ophthalmosaurus paddle in the collection represents the 'first paddle of this species that was ever known to have all the bones in the right position. I got each bone out and numbered it- \& made a drawing of the paddle as it lay in the clay'. This drawing was not sent to Dublin, and during the course of this current work, the illustration in question was traced (see Fig. 8). It was found to still be in the possession of the Leeds family, as a part of Plate 23 of E.T. Leeds unpublished 1938/9 manuscript 'Eyebury and the Leeds Collection', from which W.E. Swinton, as editor, produced the posthumous volume The Leeds Collection of fossil reptiles in 1956. The illustration is reproduced for the first time here (Fig. 8B), and has proved invaluable in reconstructing a limb that would otherwise be problematic as Ophthalmosaurus phalanges are neither tightly packed nor close-fitting (McGowan and Motani 2003).

\section{General discussion}

The Museum of Science and Art in Dublin was established in 1877 when Ireland first took on responsibility for the funding and management of Dublin museums. The existing museum of the Royal Dublin Society was the primary contributor of palaeontological collections to the new state museum (Monaghan 1992). This new museum, however, was under the same administration as museums in London and this had two effects. For existing collections there was an increased professionalism that saw a number of external palaeontologists employed by the Dublin Museum of Science and Art as temporary curators to catalogue the existing fossil collections (Monaghan 1992), namely: Davis (1888), Kidston (1888; Liston and Sanders 2005) and Lydekker (1884, 1891). Lydekker's catalogue of the fossil vertebrate collection (1891) was in a similar style to his work on the collections in the BMNH (e.g. Lydekker 1888-90). This administrative arrangement also led to a funding regime that allowed for significant purchases of new specimens. Valentine Ball, Director of the state institutions of Science and Art in Dublin from 1883-95, —and R.F. Scharff, Keeper of Natural History (as well as other areas) from 1891-1921, were the personnel of the NMINH involved with the negotiation for and acquisition of the Leeds Collection. The intention of acquiring large vertebrate fossils seems to be connected to the palaeontological furore at the time, but also complimented and built upon previous acquisitions of fossil vertebrates (the William Lee Collection of Lias marine reptiles for example). Richard Lydekker had identified gaps in the fossil collections and had the contacts to assist in identifying potential acquisitions.

There are four main issues related to the Dublin Leeds Collection: (1) the missing material, (2) the numeration of the specimens, (3) the two different shipments and their registration process and (4) Ophthalmosaurus and the field illustration of its paddle in situ.

Some parts of the collection are missing or in confusion. Namely, the above referred Asteracanthus dorsal spine, which was not originally packed by Leeds in the shipment, but was registered (NMINH 1893.179) on 20 November 1893, so presumably was sent subsequently, as Alfred Leeds undertook to do in his letter of 12 November 1893 (Alfred Leeds to Valentine Ball, 12 November 1893-NMINH SA Letter File, 1893, Vol. 3). In addition, three teeth are missing from a batch of five isolated teeth (accession number: NMINH 1893.173). The two existing isolated teeth belong to Peloneustes and Steneosaurus (see above). A plesiosaur ventral rib (accession number: NMINH 1893.164) listed in the collection was also not found in the NMINH storage. It may be that some specimens that were painted with varnish (as a pyrite treatment) in 1979 could have subsequently been lost through pyrite decay. Four of the phalangeal elements from Ophthalmosaurus Paddle 77 (NMING F21787) are missing, whether this occurred prior to packing, in transit, or later during collection movement over the decades in Dublin is unknown.

The numbering of the specimens can be confusing. Each has been allocated three numbers-'Leeds numbers' were given by Leeds while acquiring the fossils (marked with circular or oval labels). These can be confirmed as such, as some are duplicated in the Eyebury Register of the 'Second' Leeds Collection, where entries of 'Dublin' and '1892' can be found (e.g. under the crocodiles heading for entries ' 9 ' and '12'). An 'accession number' was provisionally applied to each specimen upon its arrival at the museum, and marked with black ink directly on the bones (= the 'registration number' in the accession book). Some of the numbers are marked with white ink: these were written on the bones in 1979 when they were crated, for movement to a different storage facility. The actual official registration numbers were only applied in 2007 for the purposes of this paper (see Table 2). 
Although the payment of $£ 70$ to Leeds was made in two instalments of $£ 35$, this seems to have simply been a reflection of the necessity of spreading the purchase over two financial years, as all the material arrived in one shipment and was registered at the same time (9 November 1893).

The discovery of the long-lost diagram of the paddle of 'Ophthalmosaurus 77' was a particularly satisfactory outcome of this work. It seems most likely that the diagram was never intended to be sent, either because of its slightly imperfect nature (Alfred appears to have reworked four or five of the outlines), or because he always intended to retain it as a guide for himself to reconstruct further paddles of Ophthalmosaurus. It seems most likely that Alfred Leeds produced the diagram as a reference document to use when performing future

Table 2-List of the fossil marine reptiles in the Dublin Leeds Collection, outlining the register numbers, taxonomic identification and preserved elements.

\begin{tabular}{|c|c|c|}
\hline Register number & Taxonomic identification & Preserved element( $(s)$ \\
\hline NMING F21778 & Muraenosaurus sp. & Right scapula \\
\hline NMING F21779 & Muraenosaurus leedsi & Left femur \\
\hline NMING F21780 & Plesiosauria indet. & Right ilium \\
\hline NMING F21781 & Cryptoclidus sp. & Humerus (juvenile) \\
\hline NMING F21782 & Cryptoclidus sp. & Right humerus (juvenile) \\
\hline NMING F21783 & Pelonestes philarchus & Right femur \\
\hline NMING F21784 & Pelonestes sp. & Left humerus \\
\hline NMING F21759 & Metriorhynchus sp. & Left femur \\
\hline NMING & Plesiosaurus & Ventral rib-not located \\
\hline NMING F21760 & Steneosaurus & Scute \\
\hline NMING F21785 & $\begin{array}{l}\text { 'Cimoliosaurus eurymerus' (now } \\
\text { Cryptoclidus eurymerus) }\end{array}$ & $\begin{array}{l}1 \text { left humerus (distal part), } 1 \text { left radius, } 2 \\
\text { ulnae, } 1 \text { right ischium, } 2 \text { phalanges, } 11 \text { vertebrae } \\
\text { centra ( } 1 \text { complete), } 3 \text { rib fragments }\end{array}$ \\
\hline NMING F21786 & Cryptoclidus eurymerus & $\begin{array}{l}2 \text { humeri, } 2 \text { radii, } 2 \text { ulnae, } 25 \text { vertebrae, } 1 \\
\text { scapula, (left) half coracoid, } 1 \text { clavicle, half } \\
\text { pubis, } 28 \text { ribs, } 24 \text { neural arches }\end{array}$ \\
\hline NMING F21787 & Ophthalmosaurus icenicus & $\begin{array}{l}2 \text { humeri, } 80 \text { paddle bones, } 2 \text { coracoids, } 2 \\
\text { scapulae, } 3 \text { clavicle fragments, } 2 \text { interclavicles, } \\
2 \text { cervical ribs }\end{array}$ \\
\hline NMING F21732 & Steneosaurus edwardsi & $\begin{array}{l}\text { Cranium (anterior part), lower jaw, } 16 \text { vertebrae } \\
\text { (atlas-axis, } 6 \text { cervicals, } 9 \text { dorsals), } 1 \text { fifth } \\
\text { metatarsal, calcaneum, rib fragments }\end{array}$ \\
\hline NMING F21731 & Metriorhynchus superciliosus & Upper and lower laws, 2 ilia, 28 vertebrae \\
\hline NMING F16892 & Metriorhynchus superciliosus & Skull \\
\hline NMING F21761 & Peloneustes philacarpus & Tooth $(\times 1)$ \\
\hline NMING F21762 & Steneosauru sp. & Tooth $(\times 1)$ \\
\hline NMING F21763 & Steneosaurus sp. & Tooth $(\times 1)$ \\
\hline NMING & Unknown & Tooth $(\times 2)$-not located \\
\hline
\end{tabular}


paddle reconstructions, and never intended to send it as part of the sale to Dublin. Indeed, it seems that the link between that specimen and Dublin had been lost, insofar as the Leeds family was concerned, by the time of Alfred Leeds' death in 1917, the Eyebury Register unusually records the number '77' for Ophthalmosaurus as reused without stating which institution the previous specimen went to. Other paddle diagrams are included within the plates of E.T. Leeds unpublished manuscript as figures, but this particular diagram is unusual as it features the genus and number without referring to the destination (either institution with accession number, or Stürtz). Apart from a personal deal with Othniel Charles Marsh in 1888 , the Dublin sale was the first set of specimens collected by the Leeds family that went to an institution other than the BMNH in London, and it was to remain the only such example until the commercial relationship was established with Stürtz in 1897. As such, it may simply be that Alfred Leeds was not yet in the habit of recording which institution his specimens had gone to, as everything up until then had gone to London.

A few questions remain regarding the Dublin Leeds Collection, such as the exact horizon from which the material originated. The numbers used by Leeds can often indicate a more specific location or context from which the bones were collected through cross-referring with the Eyebury Register, but unfortunately the Dublin specimens are such an early part of what E.T. Leeds referred to as the 'Second Collection' (Leeds 1956) it has only been recorded that some of the Leeds numbers have been reused from specimens sent to Dublin. This is not surprising, given that Alfred Leeds states three years after the sale to Dublin that 'I have no memorandum of any of the bones ... I am very sorry not to be able to give you more information but I cannot remember what you had' (Letter from Alfred Leeds, 28 October 1896-NMINH, October 1896 Correspondence File). This retrospective query from Dublin may well have been the stimulus for Alfred Leeds to start keeping such records for specimens that he subsequently collected, in the Eyebury Register.

There are two types of labels applied by Leeds on Dublin specimens: circular labels with large font numbers and oval labels with small font numbers. Jeff Liston's research in Glasgow had led to the conclusion that the oval labels either represented a later generation of the collection or the three figured (100 and above) 'Miscellaneous' specimens in the Eyebury Registerthe Dublin specimens, however, do not agree with these models. The majority of the specimens have oval labels; only one specimen has solely round labels, the Steneosaurus specimen NMING F21732 (Leeds number ' 110 '). Not all the labelling is congruent, however-confusingly the skull of specimen NMING F21731 (Metriorhynchus) contains oval labels, whereas the postcranium and lower jaw have round labels. More work on other Leeds specimens will be necessary to determine if there are actually any real patterns here, but Alfred Leeds' 1896 letter states that he 'think[s] the numbers were only put on to distinguish the sets' (Letter from Alfred Leeds, 28 October 1896-NMINH, October 1896 Correspondence File), again indicating that the earlier record-keeping practices of the collection had yet to evolve into the rigorous form seen in the Eyebury Register.

The most taxonomically diverse group within the Dublin Leeds Collection are the plesiosaursrepresented by three genera. This agrees with typical Oxford Clay Formation reptile biodiversity (Martill 1991).

\section{Acknowledgements}

Thanks to Nigel Monaghan and Gareth Dyke for support and discussion. Thanks also to Matthew Parkes and Graeme Lloyd for assistance. Paolo Viscardi provided access to the stores and Kimberly Eileen Lum interpreted handwritten correspondence. Mark Evans and Mark Young gave additional comment on an early draft of this paper. In particular, thanks are extended to Julian Leeds and the Leeds family for access to and permission to use E.T. Leeds' unpublished manuscript with the long-lost illustration of 'Ophthalmosaurus 77'.

\section{References}

Adams-Tresman, S.M. 1987a The Callovian (Middle Jurassic) marine crocodile Metriorhynchus from central England. Palaeontology 30, 179-94.

Adams-Tresman, S.M. 1987b The Callovian (Middle Jurassic) teleosaurid marine crocodiles from central England. Palaeontology 30, 195-206.

Andrews, C.W. 1895 On the development of the shoulder girdle of a plesiosaur (Cryptoclidus oxoniensis Phillips, sp.) from the Oxford Clay. Annals and Magazine of Natural History 15, 333-46.

Andrews, C.W. 1910 A descriptive catalogue of the marine reptiles of the Oxford Clay, part I. London. British Museum (Natural History).

Andrews, C.W. 1913 A descriptive catalogue of the marine reptiles of the Oxford Clay, part II. London. British Museum (Natural History).

Arkell, W.J. 1933 The Jurassic system in Great Britain. Oxford. Clarendon Press.

Baur, G. 1887 Ueber den Ursprungd er Extremitatend er Ichthyopterygia. Berichte iiber die Versammlungend es Oberrheinischeng eologischen Vereines 20, 17-20.

Benton, H.J. and Clark, J.M. 1988 Archosaur phylogeny and the relationships of the Crocodylia. In M.J. Benton (ed.), The phylogeny and classification of tetrapods, vol. 1, 295-338. Oxford. Clarendon Press. 
British Association for the Advancement of Science 1894 Report of the Sixty-Third Meeting of the British Association for the Advancement of Science, held at Nottingham in September 1893. London. John Murray.

Brown, D.S. 1981 The English Upper Jurassic Plesiosauroidea (Reptilia) and a review of the phylogeny and classification of the Plesiosauria. Bulletin of the British Museum (Natural History), Geology 35, 253-347.

Caldwell, M.W. 1997 Limb osteology and ossification patterns in Cryptoclidus (Reptilia: Plesiosauroidea) with a review of sauropterygian limbs. Journal of Vertebrate Paleontology 17, 295-307.

Davis, J.W. 1888 Catalogue of the collection of fossils of fossil fishes in the Science and Art Museum. Dublin. Dublin Museum of Science and Art.

de Blainville, H.D. 1835 Description de quelques espèces de reptiles de la Californie, précédée de l'analyse d'un system general d'Erpetologie et d'Amphibiologie. Nouvelles Annales du Muséum (National) d'Histoire Naturelle, Paris 4, 233-96.

de Blainville, H.D. 1853 Lettre de Monsieur de Blainville. In E. Deslongchamps (ed.), Lettres sur les Crocodiles vivants et fossiles, 103-38. Mémoires Société Linnéenne de Normandie, 9. Caen.

Duff, K.L. 1975 Paleoecology of a Bituminous shale - the Lower Oxford Clay of central England. Palaeontology 18 (3), 443-82.

Eudes-Deslongchamps, J.A. 1868 Observations faites sur le foetus du caïman à museau de brochet, et constatation d'un fait très important dans l'anatomie des Crocodiles. Bulletin de la Societé Linnéene de la Normandie 2(3), 222-5.

Eudes-Deslongchamps, J.A. 1867-9 Prodrôme des Téléosauriens du Calvados. Notes Paléontologiques. Caen 1, 9-354.

Fitzinger, L. 1843 Systema Reptilium. Vienna. Bramüller \& Seidel Ed.

Fraas, E. 1901 Die Meerkrkodile (Thalattosuchia n.g.) eine Sauriergruppe der Juraformation. Jahreshefte des Vereins für vaterländische Naturkunde in Württemberg 57, 409-18.

Gandola, R., Buffetaut, E., Monaghan, N., and Dyke, G. 2006 Salt glands in the fossil crocodile Metriorhynchus. Journal of Vertebrate Paleontology 26(4), 1009-10.

Geoffroy Saint-Hilaire, É. 1825 Recherches sur l'organisation des Gavials, sur leurs affinités naturelles desquelles résulte la nécessité d'une autre distribution générique. Gavialis, Teleosaurus, Steneosaurus. Mémoires du Muséum Histoire Naturelle 12, 97-155.

Geoffroy Saint-Hilaire, É. 1831 Recherches sur de grands sauriens trouvés à l'etat fossile aux confines maritimes de la BasseNormandie, attribués d'abord au Crocodile, puis détermines sous les noms de Teleosaurus et Steneosaurus. Mémoires de Academie des Sciences 12, 1-138.

Gray, J.E. 1825 A synopsis of the genera of reptiles and Amphibia, with a description of some new species. Annals of Philosophy 26, 193-217.

Hay, O.P. 1930 Second bibliography and catalogue of the fossil vertebrata of North America. Washington, DC. Carnegie Institute Washington.

Kidston, R. 1888 Catalogue of the collection of Palaeozoic plants in the Science and Art Museum. Dublin. Dublin Museum of Science and Art.

Leeds, E.T. 1938/9 Eyebury and the Leeds Collection. Unpublished MS., Leeds family papers.

Leeds, E.T. 1956 The Leeds Collection of fossil reptiles from the Oxford Clay of Peterborough. Oxford. Blackwell.

Liston, J.J. and Noè, L.F. 2004 The tail of the Jurassic fish Leedsichthys problematicus (Osteichthyes: Actinopterygii) collected by Alfred Nicholson Leeds-an example of the importance of historical records in palaeontology. Archives of Natural History 31, 236-52
Liston, J.J. and Noè, L.F. 2008 'Old Bones': The dinosaurs of Alfred Leeds. In R. Moody, E. Buffetaut, D. Martill and D. Naish (eds), Dinosaurs (and other extinct saurians) a historical perspective, 13-14. Abstracts of Meeting held on the 6-7 May 2008, Geological Society London. London. Geological Society London.

Liston J.J. and Sanders H.L. 2005 The 'other' Glasgow boys: the rise and fall of a school of palaeobotany. In A.J. Bowden, C.V. Burek and R. Wilding (eds), History of palaeobotany: selected essays, 197-228. London. Geological Society London.

Lydekker, R. 1884 Catalogue of vertebrate fossils from the Siwaliks of India, in the Science and Art Museum, Dublin. Scientific Transactions of the Royal Dublin Society 3, 69-86.

Lydekker, R. 1889 On the remains and affinities of five genera of Mesozoic reptiles. Quarterly Journal of the Geological Society 45 (1-4), 41-59.

Lydekker, R. 1888-90 Catalogue of the fossil Reptilia and Amphibia in the British Museum (Natural History), London. London. British Museum (Natural History).

Lydekker, R. 1891 Catalogue of the fossil mammal birds, reptiles and amphibians in the Science and Art Museum. Dublin. Dublin Museum of Science and Art.

Maisch, M.W. and Matzke, A.T. 2000 The Ichthyosauria. Stuttgarter Beiträge zur Naturkunde 298B, 1-159.

Martill, D.M. 1991 Marine Reptiles. In D.M. Martill and J.D. Hudson (eds), Fossils of the Oxford Clay. London. The Palaeontological Association.

McGowan, C. and Motani, R. 2003 Ichthyopterygia. In Friedrich Pfeil (ed.), Handbook of Paleoherpetology, part 8. Munich. Verlag Dr. Friedrich Pfeil.

Monaghan, N.T. 1992 Geology in the National Museum of Ireland. Geological Curator 5(7), 275-82.

Neaverson, E. 1935 Reptiles from the Oxford Clay of Peterborough in the geological collection of the University of Liverpool. Proceedings of the Liverpool Geological Society 16, 234-62.

Owen, R. 1840 Report on British fossil reptiles. Report of the British Association for the Advancement of Science 9, 43-126.

Phillips, J. 1871 The geology of Oxford and the valley of the Thames. Oxford. Clarendon Press.

Sander, P. Martin 2000 Ichthyosauria: their diversity, distribution, and phylogeny. Palaeontologische Zeitschrift 74, 1-35.

Seeley, H.G. 1869 Index to the fossil remains of Aves, Ornithosauria and Reptilia, from the secondary system of strata arranged in the Woodwardian Museum of the University of Cambridge. Cambridge. Deighton, Bell \& Co.

Seeley, H.G. 1874a Muraenosaurus leedsii, a plesiosaurian from the Oxford Clay, part I. Quarterly Journal of the Geological Society of London 30, 197-208.

Seeley, H.G. 1874b On the pectoral arch and forelimb of Ophthalmosaurus, a new ichthyosaurian genus from the Oxford Clay. Quarterly Journal of the Geological Society of London 30, 696-707.

Seeley, H.G. 1874c Note on some of the generic modifications of the Plesiosaurian pectoral arch. Quarterly Journal of the Geological Society of London 30, 436-49.

Seeley, H.G. 1892 The nature of the shoulder girdle and clavicular arch in Sauropterygia. Proceedings of the Royal Society of London 51, 119-51.

Smellie, W.R. 1916 Apractocleidus teretipes: a new Oxfordian plesiosaur in the Hunterian Museum, Glasgow University. Transactions of the Royal Society of Edinburgh 51(19), 89-92.

Steel, R. 1973 Crocodylia, pt 16. In O. Kuhn (ed.), Encyclopedia of palaeoherpetology. Stuttgart. Gustav Fischer Verlag.

Tarlo, B. 1960 A review of the Upper Jurassic pliosaur. British Museum (Natural History). Geology 4, 145-89.

Vignaud, P. 1995 Les Thalattosuchia, crocodiles marins du Mésozoïque: systématique, phylogénétique, paléoécologie, 
biochronologie et implications paléogéographiques. $\mathrm{PhD}$ thesis, University of Poitiers, France.

von Meyer, H. 1830 Achte versammlung der naturforscher und aerzte zu Heidelberg im September 1829. Mineralogische Abteilung, 15, 2 Isis v. Oken. 4/5/6, 517-19.

Walker, A.D. 1970 A revision of the Jurassic reptile Hallopus victor (Marsh), with remarks on the classification of crocodiles.

\section{RICARDO ARAÚJO}

Dep. de Ciências da Terra,

Fac. de Ciências e Tecnologia,

Univ. Nova de Lisboa 2829-516 Caparica,

Portugal.

ADAM STUART SMITH (corresponding author)

Department of Geology,

Museum Building,

Trinity College Dublin, Dublin 2,

Ireland.

E-mail:assmith@tcd.ie
Philosophical Transactions of the Royal Society of London, Series B, Biological Sciences 257 (816), 323-72.

Williston, S.W. 1925 The osteology of the reptiles. Cambridge, MA. Harvard University Press.

Woodward, A.S. 1917 Obituary: Alfred Nicholson Leeds, F.G.S. Geological Magazine. Decade VI, 4, 478-80.

\section{JEFF LISTON}

Hunterian Museum,

University of Glasgow,

Glasgow,

G12 8QQ,

Scotland. 